\title{
Optimalization of Mathematical Learning Outcome by Using the Smart Boxes Media at Primary School
}

\author{
Darmiyati, Mahrita Ayu Mustikasari \\ Primary Teacher Education Study Program \\ Faculty of Teacher Training and Education \\ Universitas Lambung Mangkurat \\ Banjarmasin, Indonesia \\ darmiyati@unlam.ac.id
}

\begin{abstract}
The materials in mathematics taught to elementary school-aged children who are still in the stage of pre-operational concrete thinking are abstract. This leads to difficulties for students in understanding the materials particularly the properties of build space which in turn impacted students' learning outcomes. This study aims to analyze the application of smart boxed media on teacher activity, student activity, and student learning outcomes. This type of research is a Class Action Research (Penelitian Tindakan Kelas, CAR) conducted in 4 cycles. This research was carried out at SDN Cindai Alus 1 Kabupaten Banjar in semester 2 (even) academic year 2016/2017. The subjects of this research were grade $V$ students with a total number of 33 persons. Based on the results of this study it can be concluded that the implementation of Connecting Organizing Reflecting Extending learning model, combined with Group Investigation, Course Review Horay and Smart Boxes media increased teacher's activity, students' activity and learning outcomes. So, it is suggested for teachers to implement them as alternative strategies in teaching and learning Mathematics.
\end{abstract}

Keywords_Learning Outcomes, Smart Boxes Media.

\section{INTRODUCTION}

Education plays an important role in preparing quality human resources and the ability to compete in the development of science and technology, so education must be carried out as well as possible to get maximum results. Education should be managed, both in quality and quantity. This can be achieved by implementing timely and appropriate education to achieve learning objectives. In line with efforts to develop science and technology, schools are formal educational institutions. Professional teachers are needed to support the learning process. Teacher professionalism is very necessary in carrying out the learning process. Professional teachers who are able to teach well will certainly prepare qualified the next generation and quality learning. A teacher is required to be able to display innovative and creative learning and attracts students to actively engage in creativity [1].
Mathematics is one of the subjects in school in which its application is very closely related to everyday life. It cannot be denied that mathematical concepts are important for every human activity: starting from waking up to transacting to make ends meet. Mathematics is one of the disciplines that can improve the ability to think and argue, contribute to solving everyday problems and in the world of work, and provide support in the development of science and technology [2].

Teaching mathematics in elementary schools has important goals in life, especially for community life. Mathematics learning is a teaching and learning process that is built by the teacher to develop students 'thinking creativity that can improve students' thinking skills, and can improve the ability to construct new knowledge as an effort to improve good mastery of the material mathematics [2]. In fact elementary school children often experience difficulties with math lessons. This is due to the use of symbols that make them feel confused about them. This makes them difficult for students to understand mathematical concepts and often get unsatisfactory grades so that they assume that mathematics is a difficult, boring and confusing lesson. Many students feel that mathematics is the most difficult and frightening subject for them.

Other causes are also because students are not directly involved in the learning process so that they become less active. As a result, they cannot develop their ability to think critically and inhibit their creativity in the learning process. Based on observations and interviews with teachers and students in grade 5 SDN Cindai Alus 1 several problems in learning mathematics, especially in the material "Building Space" were found. Students had a hard time in understanding the concept of building space itself. Students also find it difficult to remember various characteristics of building space, due to the large number of spaces that students must remember. This resulted in students often getting less satisfactory grades from the defined KKM which was 65 .

It can be seen from the results of the achievement of mathematics in Class V of SDN 1 Cindai Alus of Banjar Regency in the 2016/2017 academic year. They got low scores 
which were lower than KKM, i.e. $\geq 65$. Out of 30 students only $14(47 \%)$ were successful and $16(53 \%)$ did not reach KKM. The achievement of students in learning outcomes was a problem that must be identified immediately.

Based on the results of interviews with teaching teachers in Class $\mathrm{V}$ and the documents of student scores, it turned out that the achievement for mathematics in Class V SDN 1 Cindai Alus Banjar Regency have been fully achieved; this was especially in the areas of mathematics classified as difficult. Students could not determine the properties possessed by building and mentioned their names without seeing the concrete model or object first; students were unable to remember the nature of building one by building another space.

Researchers used Connecting, Organizing, Reflecting, Excending model combined with Group Investigation Model, Course Review Horay and Smart Boxes Media to improve and overcome the causes of problems which resulted in low learning outcomes of mathematics. They were expected to increase students' motivation and maximize their active involvement in the learning process.

Connecting, Organizing, Reflecting Extending Learning model is a model that emphasizes students' thinking skills or high-level thinking to connect, organize, explore, learn, and develop information obtained. This model emphasizes students for high-level thinking in learning activities. Students are required to be able to think the information they got critically. The activity of analyzing the old-new concept, students were trained to remember new information. The activity of organizing ideas can train students' ability in organizing and managing the information they have.

Reflection activity is an activity of deepening and digging up information to strengthen the concept they have. In Extending students are trained to develop, and expand the information they have. They are acquired to use the information and be able to find new concepts and information that are more useful. So that the children can know the right knowledge.

The second model is the first model supporting the Group Investigation model. Learning with this method aims to enable students to communicate both with their own friends and teachers, learn to communicate well systematically, learn to respect the opinions of others and can increase their participation in making decisions. The researcher also added a third model as a complement, i.e. using the Course Review Horay learning model. The model made the learning environment alive because the teaching and learning process was interspersed with playing. This can increase the spirit of students in learning. It can generate interest and motivate students to actively learn. The two models the researchers used required students to think critically and at a high level. This model could make students enthusiastic in the learning process.

Researchers also used Smart Boxes Media as support in the learning process. Smart Boxes Media are made by the researchers to assist the learning process. Smart Boxes Media, made to resemble building in general, are media that are made from unused cardboard and then wrapped in manila paper or paperboard so that students were interested in learning activities. Of course, Smart Boxes Media were environmentally friendly learning media because they were made of used materials and were easily found.

The combination of the Connecting Organizing Reflecting Extending learning model combined with the Group Investigation Model, Course Review Horay and Smart Boxes Media would cause interaction between students through discussion. Then students were taught how to work together in groups that demanded to share responsibility in solving problems, so that the the difficult materials on properties of building spaces would be easy to be done together; they would also make students more independent without having to expect teacher assistance and only direct a little, so that students' activities were not passive and more dominant.

Seeing the problems that occured the researchers attempted to overcome this problem by conducting a classroom action research entitled "Optimalizing Mathematics Learning Outcomes by Using Smart Boxes Media at Primary School". This study aims to analyze the application of smart boxed media on teacher activity, student activity, and student learning outcomes.

\section{METHOD}

This study used Classroom Action Research (CAR). Classroom action research is an attempt to examine the learning activities of a group of students by providing an action (treatment) that is deliberately raised. The action is carried out by the teacher, by the teacher together with students, or by students under the guidance and direction of the teacher, with a view to improving and improving the quality of learning [3].

The Classroom Action Research Procedure includes four steps: (1) Planning is the selection of observers, making learning scenarios, preparing facilities needed in the classroom, preparing observation instruments and analyzing data regarding the process and results of actions. (2) Implementation is the implementation of actions carried out covering who is doing, what, when, where, and how. (3) Observation is the recording of data including the process and results of the implementation of activities. (4) Reflection is the result of the observation analyzed so that it is known the extent of the success of the research also to find out the shortcomings to be improved.

This study used a combination of learning models Connecting, Organizing, Reflecting, Excending combined with a Model Investigation Group, Course Review Horay and Smart Boxes Media with the following steps: a. The teacher begins learning with activities that attract students by singing songs related to material to stimulate student motivation; $b$. The teacher conveys all learning objectives and competencies to be achieved, conveys old concepts that will be linked to new concepts and divides students into heterogeneous groups; c. The teacher asks students to choose subtopics that have been provided and then share Smart Boxes media to each group; d. The teacher demonstrates building material using 
Smart Boxes Media and provides opportunities for students to ask questions; e. The teacher asks the students to make a box on the paper then it is filled with numbers and the teacher reads the questions randomly and the students write the answers in the box whose number is mentioned by the teacher; f. The teacher guides students to discuss, think about, and explore information. For questions that are answered correctly, students mark $(\sqrt{ })$ and shout "horee"; g. The teacher gives rewards to groups that get the highest score; $h$. The teacher guides students to conclude learning; i. The teacher asks students to answer the evaluation sheet.

Factors examined in this classroom action research include, (1) teacher activity using the Connecting, Organizing, Reflecting, Excending learning model combined with the Group Investigation Model, Course Review Horay and Media Smart Boxes, (2) student activities in following the learning process using a combination of learning models of Connecting, Organizing, Reflecting, Excending learning models combined with the Investigation Group Model, Course Review Horay and Smart Boxes Media, (3) learning outcomes after participating in the learning material on the nature of space with a combination of learning models Connecting learning models, Organizing, Reflecting, Excending is combined with the Group Investigation Model, Course Review Horay and Smart Boxes Media through evaluation tests at the end of the meeting by using an evaluation sheet that is measured quantitatively.

Sources of data in this study were teachers and VB grade students of SDN 1 Cindai Alus 1 Banjar Regency in the second semester of the 2017/2018 school year in the material learning process the properties of space were obtained from teacher activity observation sheets, observation sheets of student activities and learning evaluation results at the end of each meeting.

Data analysis techniques used include qualitative and quantitative analysis (1) Qualitative analysis in the form of data about teacher activities in carrying out learning and student activities in following the learning and activities of students in groups on learning material properties of building space through a combination of Connecting, Organizing, Reflecting, Excending is combined with the Group Investigation Model, Course Review Horay and Media Smart Boxes (2) Quantitative analysis is obtained from the final test results using written questions. Quantitative assessment to determine the success of students in following the learning of student activities in groups on the material properties of space through learning learning models Connecting, Organizing, Reflecting, Excending combined with Group Investigation Models, Course Review Horay and Smart Boxes Media. Data analysis of student learning outcomes is done by counting the number of students who complete the written test at the end of each meeting with the material that has been given during the learning process. Indicators of success of this study are: 1. Teacher activity is declared successful if it reaches a minimum of good categories from a range of 30-36 scores with very good categories. 2. Student activity is declared successful if $80 \%$ of the number of students have reached the minimum active category .. 3. Individual student learning outcomes are declared successful when achieving a minimum score of 65 , and classically if $80 \%$ of the number of students get a minimum score of 65 with complete criteria.

\section{RESULT AND DISCUSSION}

Teacher activities in each cycle always increase. We can see this through the graph below:

\section{A. Teacher activities}

Based on Figure 1 above in cycle I to cycle IV in learning activities using a combination of Model Connecting, Organizing, Reflecting, Extending combined with the Group Investigation Model, Course Review Horay and Smart Boxes Media, each cycle consists of 4 meetings can be concluded that teacher activities continue to increase and succeed in achieving very good criteria. scores obtained from each meeting have increased. Starting from the first cycle of meeting 1 the score obtained by the teacher was 24 with a fairly good category. This result increased in cycle II meeting 2 to 27 with good category. Continuing on the third cycle of the third meeting the scores obtained by the teacher again increased to 33 in the very good category. Then it increased again in the fourth cycle of the IV meeting to 34 with a very good category

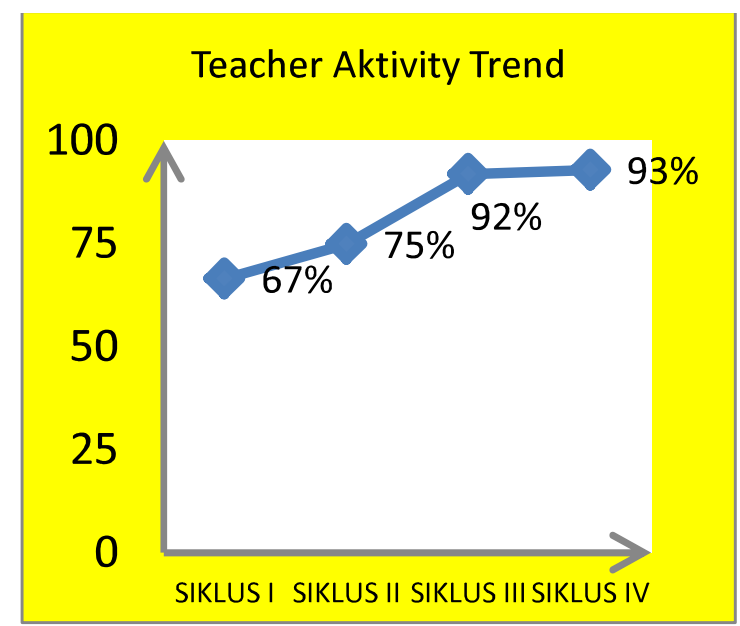

Fig. 1. Results of Teacher Activities in Each Cycle

Increased teacher activity in this activity is also based on the selection of the right learning strategies and models and what materials will be delivered and how to use the appropriate learning media used in learning. This is in line with the opinion of [4] who argued that the choice of learning strategies used in the learning process must be oriented towards the learning objectives to be achieved. In addition, it must be adapted to the type of material, the characteristics of students and the prospective situation, the conditions under which the learning process will take place.

The learning process that takes place will affect the activeness and motivation of learners in learning and the use of the right learning model will also make learning activities conducted by the teacher more meaningful. The role of the teacher is very important in creating a pleasant classroom atmosphere and makes students active in learning so that learning can be carried out according to plan. 
As [5] argues that in cooperative learning, the teacher acts more as a facilitator which serves as a bridge to higher understanding, with the student's own notes. The teacher not only provides knowledge to students but also must build knowledge in his mind. This shows that the use of learning strategies conducted by teachers in the classroom has a very important role to improve the achievement of learning goals. This is what ultimately underlies researchers to apply the right learning model in the learning process. The results obtained are an increase in the quality of learning done by the teacher and can be seen clearly from the increase in teacher activity scores at each meeting.

This is in line with [6] which reveals that a teacher must guide students to be able to carry out their development tasks well and uniquely. An important point in the guidance process is the full involvement of students. Because guidance is the process of providing assistance to students. So, the teacher must actively involve students so that the mentoring process runs effectively.

\section{B. Student Activity}

Based on Figure 2 above the results of observations of individual student activities carried out by the teacher, it appears that student activities from each meeting continue to experience enhancement. Starting in the first cycle of meeting 1 , only $44.15 \%$ of students were very active. This was later corrected by the teacher in the second cycle of meeting 2 to be $74.88 \%$ of students in the very active category. In the next learning the teacher continues to improve performance in the learning process so that the results obtained in the third cycle of meeting 3 become $86.57 \%$ of students who are very active. Then this was corrected by the teacher so that it increased in the fourth cycle of meeting 4 to $92.19 \%$ of students who were very active.

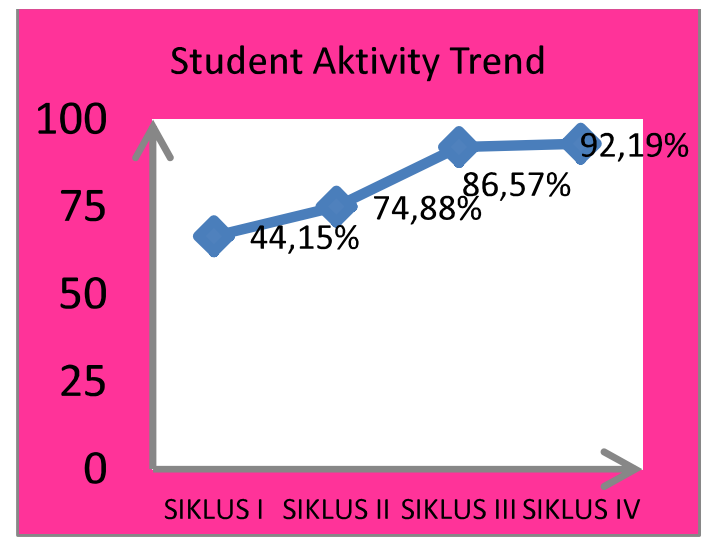

Fig. 2. Results of Student Activities in Each Cycle

In the Connecting, Organizing, Reflecting, and Extending learning models combined with the Group Investigation Model, Course Review Horay and Smart Boxes media students are required to collaborate with friends in forming groups. This is reinforced by Artzt \& Newman [7] states that in cooperative learning students learn together as a team in completing group tasks to achieve common goals. Each group member has the same responsibility for the success of the group.
This learning requires students to cooperate where students who already understand can help other members who do not understand yet, it is in accordance with [8] opinion that cooperative learning has two main components, cooperative task components that cause members of the cooperative incentive structure to arouse individual motivation to work together to achieve group goals.

When students are given a worksheet a group of students work together and help each other in increasing the success of the group. Increased success in individuals and groups is evident in their implementation and this is in accordance with what [9] explained that: 1) students work together in achieving goals by upholding group norms, 2) students actively helping and motivating the spirit to succeed together, 3) actively acting as peer tutors to further enhance group success. 4) interaction between students along with their ability to improve in opinion, 5) improve individual skills and improve group skills.

Cooperative learning model is a learning model that prioritizes groups. Every student in the group has different levels of ability (high, medium, and low) and if possible group members come from different races, cultures, tribes and pay attention to gender equality. This is in line with the opinion of [10] stating that "teachers always encourage students to active learning, both for individual work, group work or just encourage to think" in other words, learning requires activities, without learning process it may not work well.

\section{Learning Outcomes}

Based on Figure 3. below student learning outcomes in the material properties of space show an increase in each meeting. In the first cycle of meeting 1 there were $50 \%$ of students who were completed, then increased in cycle II meeting 2 to $63.88 \%$ of students who completed. This result can be increased again in the third cycle of meeting 3 to $74.19 \%$ of students complete. Then in the fourth cycle, the fourth meeting was $86.11 \%$ of students who were finished.

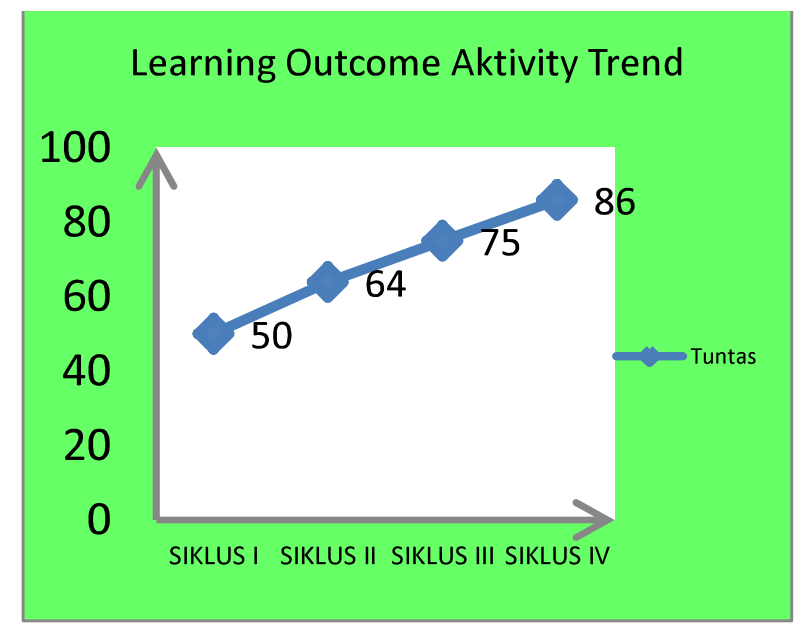

Fig. 3. Student Learning Outcomes for Each Cycle

As stated by Nawawi learning outcomes are the level of student success in learning a subject matter that is assessed by a certain score through a number of tests [2]. Assessment of learning outcomes is all kinds of procedures used to obtain 
information about student performance or how far students understand learning [11].

Learning outcomes are also a goal to be achieved from a teaching and learning activity. The role of the teacher in the learning process is also the key to success in making learning outcomes good. The success of students in obtaining a score depends on the lessons implemented by the teacher. Teacher's actions greatly affect student learning outcomes. According to Nawawi learning outcomes can be interpreted as the level of success of students in studying school subject matter expressed in the scores obtained from the test results recognize a number of specific subject matter [2].

The student's memory is unfaithful, so it needs to be helped by repeating the lesson being explained. The lessons that are repeated will give a clear response, and are not easily forgotten. By repeating the lesson, it will improve student learning outcomes. The increase and decrease in the value of student learning test results are also influenced by several factors both internal and external factors. The internal factors are factors experienced and internalized by students that affect student learning outcomes, while external factors such as teachers, learning facilities and infrastructure, and the social environment of school students also influence learning outcomes [12].

In line with the above opinion [2] states that the learning outcomes achieved by students are influenced one of them by one's intelligence abilities which greatly affect the fast and slow acceptance of information and whether or not a problem is divided. The increase in learning outcomes also occurs because the teacher during the learning process not only provides material in lectures but the teacher attaches importance to the group discussion process as a means of building information and knowledge through exchanging opinions and learning from each other while the teacher is only as a facilitator and mentor [7].

As we know that one of the factors that influence student learning outcomes is motivation, motivation is very necessary to be given to students so that students can be enthusiastic in learning. Motivation is a physiological and psychological condition contained in a person who encourages him to carry out certain activities in order to achieve a goal (need) [13].

The success of student learning outcomes is because the teacher is very good at mastering the material being taught, and the impact on students is very good in working on the problem, proved that only a few students were unable to do the questions. The teacher always tries to maximize student learning and the teacher is very good in using a variety of Connecting Organizing Reflecting Extending learning models, Group Investigation, Course Review Horay and Media Smart Boxes so as to be able to help students understand the material and be able to improve student learning outcomes.

Based on Figure 3 it can be seen that all aspects examined always experience an increase at each meeting. In teacher activities, student activities and learning outcomes tend to increase very well. The improvement of the three aspects studied is interrelated with each other. It can be said that the increase in teacher activity which is getting better has an impact on student activity which is getting better so as to produce better student learning outcomes in each learning.

So the hypothesis that reads: "When applied to the Connecting, Organizing, Reflecting, and Extending Learning Models combined with the Group Investigation Model, Course Review Horay and Smart Boxes media in mathematics lessons the material for identifying simple spaces can improve student learning outcomes in class V SDN Cindai Alus 1 Banjar Regency "can be accepted.

\section{CONCLUSION}

Based on the results of data analysis and discussion of research that has been carried out through the implementation of classroom action research in learning can be summarized as follows: (1) The teacher's activity has reached the indicator of success that is minimal obtaining good criteria. (2) Student activity has reached the indicator of success, namely the activity of students has reached very active criteria. (3) Learning outcomes after participating in material learning about the nature of space using a combination of Connecting Organizing Reflecting Extending learning models, Group Investigation, Course Review Horay and Media Smart Boxes can increase student learning outcomes in VB class at SDN Cindai Alus 1 Banjar Regency.

\section{REFERENCES}

[1] J. Suprihatiningrum, Strategi Pembelajaran Teori \& Aplikasi. Yogyakarta: Ar-ruzz Media, 2013

[2] A. susanto, Teori Belajar dan Pembelajaran di Sekolah Dasar. Jakarta: Kencana, 2013

[3] M. Mulyasa, Praktik Penelitian Tindakan Kelas. Bandung: PT. Remaja Rosdakarya, 2011.

[4] H. B. Uno and M. Nurdin, Belajar dengan Pendekatan PAILKEM. Jakarta: PT Bumi Aksara, 2014.

[5] R. Rusman, Model-model Pembelajaran Mengembangkan Profesionalisme Guru. Jakarta: PT Rajagrafindo Persada, 2014.

[6] H. Hartono, Pengantar Ilmu Pendidikan. Bandung: PT. Remaja Rosdakarya, 2014

[7] T. Trianto, Model Pembelajaran terpadu. Jakarta: PT. Bumi Aksara, 2015.

[8] A. Suriansyah and Dkk, Strategi pembelajaran. Depok: Rajagrafindo Persada, 2014.

[9] A. Shoimin, 68 Model Pembelajaran Inovarif dalam Kurikulum2013. Yogyakarta: AR-Ruzz Media, 2014.

[10] A. . Sardiman, Interaksi \& Motivasi Belajar Mengajar. Jakarta: PT RajaGrafindo Persada, 2007.

[11] E. Siregar and H. Nara, Teori Belajar Dan Pembelajaran. Bogor: Ghalia Indonesia, 2014

[12] D. Dimyati and M. Mudjiono, Belajar dan Pembelajaran. Jakarta: PT Rineka Cipta, 2013.

[13] D. Djali, Teori Belajar dan Pembelajaran. Jakarta: AR-Ruzz Media, 2013. 